\title{
STUDY OF THE USE OF MULTI-TRIP CARD FOR TRANSPORTATION IN JAKARTA
}

\author{
Hardika Pratama $^{1}$, Mundziri Pratiknyo ${ }^{2}$, Abdullah Ade Suryobuwono ${ }^{3}$ \\ 1. STMT Trisakti, 2. STMT Trisakti, 3. STMT Trisakti \\ $\triangle$ Corresponding author : hardikapratama5@yahoo.com
}

\begin{abstract}
The more and more progress in technology especially in transportation urge the more sophisticated and easier in implementation. Due to the high volume of urbanization also need the transportation system getting high, therefore the government especially Jakarta is speeding the development in mass transportation. All mass transportation especially in rail system are being set up, and they will be integrated with other system. To complete and to ease passengers pay the cost, government should apply the multi-trip ticketing system as well. This observation uses qualitative research method by collecting data based on interview conducted and direct observation to the field. The data record should be studied by using comparative study based on the same case of Germany, Austria, Switzerland, and England empirically. By getting implementation ticketing system of other country, we can compare which is better to be implemented in our city. The study gives some results like; (1) Integration of the ticketing system's condition is not yet done; (2) Ticketing system of London is very suitable to be applied in Jakarta; (3) To implement multi-trip card in Jakarta should be done step-by-step.

Keywords: Multitrip ticketing, Implementing ticketing system, Integrated transportation, transportation management, E-ticketing
\end{abstract}

\section{Introduction}

Transportation is very important particularly to support our business, heavy traffic jam in any big cities which is getting worse would be a task for government to find out the solution. Nowadays, people mobility is getting higher which is not possible to use private vehicle, this will make the road getting crowded and full if various vehicles.

The government presently is fastening development particularly in mass transportation to create the simple, comfortable, and to fasten the movement of goods or people from one place to other place.

The public mode of transportation contributes over dwindling use of private vehicles as a result of the passenger capacity of the relatively greater. A real action over improvement public transportation of them increase transjakarta buses with various improvements facilities, stop the operation several buses city who has not be used with the purpose of reducing jam level and the community turn to public transport safer and comfortable (Ashari dan Ismiyati, 2016). 
To make people interested to take mass transportation, transportation technology must be applied to easier passengers in taking such transportation i.e commuter line, BRT, MRT, LRT, and Airport's train.

Table 1. The total passengers of Transjakarta and Jabotabek Train on 2014 \& 2015

\begin{tabular}{|c|c|c|}
\hline \multirow{2}{*}{ Transportation mode } & \multicolumn{2}{|c|}{ Year } \\
\cline { 2 - 3 } & 2014 & 2015 \\
\hline Transjakarta & 111.630 .305 & 102.950 .384 \\
\hline Jabotabek Train & 208.494 .094 & 257.530 .185 \\
\hline
\end{tabular}

Source: Badan Pusat Statistik

Based on the above data, the number of passengers in Jakarta Mass Transportation raised, and it must be followed by hi-tech system including the easy and efficient way to access the mass transportation (Transjakarta \& Commuter Line).

It seems the government is making effort to create hi-tech community, especially in transportation system. During the globalization era which is going very fast, we are all claimed to follow the sophisticated information technology system in all activities including transportation.

The sophisticated transportation and eliminated manual system that makes long time of travel will make community interest to use mass transportation on land, railway, sea or in the air. Therefore we need to create an innovation of payment ticketing system which is integrated and enable passengers to move from one place to other place. The multi-trip ticketing system can make easily of passengers moving to other transportation mode and it is expected can fasten to their destination and the important thing is private vehicle user can turn to public transportation.

Problem Identification

1. Many of transportation mode haven't integrated.

2. Transportation ticketing system haven't integrated yet.

3. It's not easy for passengers to change from one mode transportation to other mode.

4. People interest to use mass transportation is still not so high.

5. Passengers have quite a lot of cards they want to take mass integrated transportation. 


\section{Purpose}

1. To acknowledge ticketing system in mass transportation in Jakarta.

2. To be a reference to compare with other countries' system.

3. To analyze of multi-trip ticketing application on mass transportation in Jakarta, Indonesia.

Table 2. Comparison of previous screening

\begin{tabular}{|c|c|c|c|c|c|c|}
\hline NO & TITLE & RESEARCHER & DESCRIPTION & $\begin{array}{l}\text { RESEARCH } \\
\text { METHODS }\end{array}$ & $\begin{array}{l}\text { ANALYSIS } \\
\text { METHODS }\end{array}$ & CONCLUSION \\
\hline 1. & $\begin{array}{l}\text { Integrated } \\
\text { Ticketing } \\
\text { System Of } \\
\text { Public } \\
\text { Transport In } \\
\text { Jakarta Vs } \\
\text { Värmland, } \\
\text { Sweden } \\
(2013)\end{array}$ & $\begin{array}{l}\text { Teguh Himawan } \\
\text { Ronggosusanto }\end{array}$ & $\begin{array}{l}\text { This study tries } \\
\text { to give } \\
\text { contribution for } \\
\text { the expansion of } \\
\text { integrated } \\
\text { ticketing system } \\
\text { compared with } \\
\text { country of } \\
\text { Sweden system. }\end{array}$ & $\begin{array}{l}\text { Qualitative } \\
\text { screening } \\
\text { approach }\end{array}$ & $\begin{array}{l}\text { Using study } \\
\text { case of } \\
\text { Värmland, } \\
\text { Sweden as } \\
\text { based theory } \\
\text { and his } \\
\text { study } \\
\text { comparison } \\
\text { to create } \\
\text { new service. }\end{array}$ & $\begin{array}{l}\text { Transjakarta \& } \\
\text { Commuter line } \\
\text { operators should } \\
\text { have same } \\
\text { perception in } \\
\text { calculating the } \\
\text { fare so that } \\
\text { tickets can be } \\
\text { used for both } \\
\text { mode } \\
\text { (Transjakarta \& } \\
\text { Commuter line) }\end{array}$ \\
\hline 2. & $\begin{array}{l}\text { Implementasi } \\
\text { E-Ticketing } \\
\text { Dalam } \\
\text { Transjabodet } \\
\text { abek Untuk } \\
\text { Mewujudkan } \\
\text { Integrasi } \\
\text { Transportasi } \\
\text { Di } \\
\text { Jabodetabek } \\
\text { (2016) }\end{array}$ & $\begin{array}{l}\text { Dwinda Rizky } \\
\text { Hadinugrah }\end{array}$ & $\begin{array}{l}\text { Transjabodetabe } \\
\text { k e-ticketing } \\
\text { implementation } \\
\text { have some } \\
\text { supporting } \\
\text { factor and } \\
\text { handicap } \\
\text { factors. }\end{array}$ & $\begin{array}{l}\text { Qualitative } \\
\text { approach }\end{array}$ & $\begin{array}{l}\text { Using some } \\
\text { implementat } \\
\text { ion like } \\
\text { supporting } \\
\text { factor and } \\
\text { handicap } \\
\text { factor. }\end{array}$ & $\begin{array}{l}\text { Transjabodetabe } \\
\text { k e-ticketing } \\
\text { have been } \\
\text { running well } \\
\text { since they had } \\
\text { good } \\
\text { communication, } \\
\text { good } \\
\text { management, } \\
\text { skillful human } \\
\text { resource and } \\
\text { disposition. }\end{array}$ \\
\hline 3 & $\begin{array}{l}\text { Identifikasi } \\
\text { Sistem } \\
\text { Pembayaran } \\
\text { Transjakarta } \\
\text { Menggunaka } \\
\text { n Smart Card } \\
\text { (2012) }\end{array}$ & $\begin{array}{l}\text { Dessy Wulandari } \\
\text { A.P. }\end{array}$ & $\begin{array}{l}\text { How can you } \\
\text { use your smart } \\
\text { card to save } \\
\text { database? By } \\
\text { using } \\
\text { microprocessor } \\
\text { chip inside the } \\
\text { card, in the term } \\
\text { of processing } \\
\text { smart card isn't } \\
\text { discussed in } \\
\text { detail. }\end{array}$ & $\begin{array}{l}\text { By collecting } \\
\text { data, } \\
\text { observation } \\
\text { and } \\
\text { document } \\
\text { study }\end{array}$ & $\begin{array}{l}\text { By } \\
\text { analiysing } \\
\text { data of } \\
\text { passengers } \\
\text { per corridor } \\
\text { in } \\
\text { Transjakarta } \\
\text {. }\end{array}$ & $\begin{array}{l}\text { By charging } \\
\text { passenger's fare } \\
\text { per corridor so } \\
\text { revenue will } \\
\text { increase. }\end{array}$ \\
\hline 4 & $\begin{array}{l}\text { Kriteria } \\
\text { Pelayanan } \\
\text { Sistem Tiket } \\
\text { Terpadu } \\
\text { Antarmoda } \\
\text { Angkutan } \\
\text { Jalan Dan } \\
\text { Pesawat } \\
\text { Terbang } \\
(2015)\end{array}$ & $\begin{array}{l}\text { Karmini dan Siti } \\
\text { Fatimah }\end{array}$ & $\begin{array}{l}\text { Integrated ticket } \\
\text { is the ticket that } \\
\text { you can use } \\
\text { either for } \\
\text { Transjakarta or } \\
\text { commuter line } \\
\text { to any } \\
\text { destination. }\end{array}$ & $\begin{array}{l}\text { Qualitative } \\
\text { and } \\
\text { quantitative } \\
\text { by survey and } \\
\text { observation } \\
\text { method. }\end{array}$ & $\begin{array}{l}\text { Index } \\
\text { analysis }\end{array}$ & $\begin{array}{l}\text { Online system } \\
\text { in the most } \\
\text { favorable way } \\
\text { of passengers to } \\
\text { buy inter-mode } \\
\text { ticket so they } \\
\text { can buy at the } \\
\text { ticket booth } \\
\text { directly } \\
\text { wherever they } \\
\text { want to leave. }\end{array}$ \\
\hline
\end{tabular}




\section{Literature Review}

A. Integrated Ticketing System

The effective interconnection will enhance efficiency and reduce damaging environment from public transport by emphasizing integration $\&$ cooperation, to provide competitive transportation service. Effective interconnection needs to serve such an integrated a friendly interesting transportation service to public. Therefore integrated ticketing system in important to have a better interconnection that allow passengers use the same ticket for different mode of transportation of all operator continuously. (seamless) (Karmini \& Siti Fatimah, 2015).

B. Integrated Transportation System

This system will enable passengers to change from one mode of transportation to different mode and setting 'fare' for interconnection bus-rail and bus rel-link service (Potter \& Skinner, 2000). The authority should provide 'park and ride' area passengers can park their vehicle here and take a bus / a train to their end destination.

With this system transportation will be faster. How can it be implemented? The authorities need to prepare various facilities such as 'park and ride' area, bus shelter that connected to commuter line's railway station, and integrated E-ticketing with one fare for entire route.

\section{Management of Transportation}

In the achievement of development, the role of road transport has a vital and strategic position, so the policy needs to be combined in a unified land transport management policy and its impact on the economy of the community. Various policies have been issued, in order to minimize the problems of the land transport, the policy will not work optimally during transportation management land less addressed. Transport is a very important element can even serve as an artery for life and economic growth of the community, political, and socio-cultural as well as the mobility of the population was able to grow and evolve to follow the dynamics of the case (Kadarisman, Gunawan, \& Ismiyati, 2016) 


\section{Intermode Transportation}

Intermode transportation constitutes the principal component of that plays a big role in making the displacement of modes of. Occurring in the intermode transportation network transportation system. An intermode transportation system integrating different geographical scales on a level national transportation service and of a corridor in local. Intermode transportation system consisting of a series of central hub that is integrated with transportation network and local areas (Irpan, Sony \& Sarinah, 2016).

\section{E. Service Quality}

Service quality is a good condition to poor cereal provided by transport service providers in order to provide satisfaction to the consumer. The quality of service a service company certainly is not something that is easy, because it is so closely associated with the consumer's view of the transport users. the driving factors of customer satisfaction, by increasing the quality of service. to assess the quality of service, can be measured through the 5 factors, i.e. physical evidence (tangible), reliability (reliability), responsiveness (responsiveness), guarantees (assurance), and attention (emphaty) (Saribanon, Sitanggang, \& Amrizal, 2016).

F. Transjakarta

It is a commonly called bus rapid transit transportation system (BRT) first brt in southeast asia and south , the bus is a flagship program of the government to develop public transport bus, is a pioneer of comfort to reform public transport, security, safety and accessibility for the community .But there are still the causes of dissatisfaction from the management which suggest that still needs to be improved .The maintenance and operational management is the need for improvements in public safety and comfort for passengers (Ismiyati, Firdaus, \& Arubusman, 2017) 


\section{Method}

This study applied qualitative observation system by collecting data from direct survey on the field and interview result. Then we analyze all the data using comparative method, we compared with other country.

\section{Discussion And Result}

A. Mass Transportation Payment System In Jakarta.

1. Ticketing System Of Transjakarta

Instead of using cash payment, Transjakarta has required to pay the ticket with e-ticketing since 2013. Local bank i.e BRI (Brizzi), BCA (Flazz), BNI (Tapcash, Kartu Aku, and Rail Card), bank Mandiri (Emoney, E-toll card, Indomaret card, and Gazcard), bank DKI (Jakcard), and bank Mega (Mega cash) issued these cards. Passengers do 'tap in' when entry the shelter of busway, then account will be deducted as much as the fare automatically. They do same thing 'tap out' when leaving / going out from the shelter, with no charge.

Transjakarta will always renew the route and give better service all passengers, based on passengers' destination.

2. Ticketing System of Commuter Line (KRL)

Ticketing system applied to the Commuter Line train is divided into 3 types according to the trip:

a. Multi-Trip

Multi-Trip Card is refillable prepaid card used as KRL ticket with minimum balance requirement. The card can only be used to KRL only and can be refilled at all KRL stations in Jakarta Bogor Depok Tangerang Bekasi area (known as Jabodetabek).

b. Single Trip or Guaranteed Daily Ticket

Single trip ticket's implementation results in the number of single trip ticket lost, therefore, it is applied ticketing system to replace single trip for KRL's passenger without subscription. Tariff calculation is in accordance with single trip travel tariff scheme, but passengers are required to pay a security deposit for THB. 


\section{c. Prepaid Card (Bank)}

Prepaid card is a money replacement card issued by bank that can be used to pay anything such as in transportation, e.g.; Flazz BCA, Mandiri E-Money, Brizzi, BRI, and BNI TapCash.

To use the card, it is the same as to use Multi-Trip Card, but the four cards cannot be bought and refilled at all KRL stations in Jabodetabek, otherwise, it can be bought in related merchants such as Indomaret, 7Eleven and all Transjakarta bus stops (cash). Refill can be done by cash or by related bank ATM card. Some KRL stations have serviced the four card refills, such as Sudirman and Juanda, but it should use a related bank ATM card (debit or credit card). The four cards can be used also as Transjakarta ticket.

Based on the statement above it can be concluded that ticketing system in its operation in Jakarta is good enough. Unfortunately, ticketing system in Jakarta is not integrated yet in all transportation mode, therefore, not all cards can be used to use mass transportation. This problem is caused by many stations and bus shelter still not integrated each other and the ticket payment system still uses an unintegrated card.

d. Feeder Service (Feeder)

Feeder service is organized by PT. Transjakarta with the aim to be able to support cities around Jakarta connected with transportation mode such as Transjakarta and Commuter Line. Feeder service owned by PT.Transjakarta is divided into 4 that is border feeder, inner city feeder, KRL station feeder, and flats feeder.

This service applies the same charged as Transjakarta bus which is Rp 3.500,00, and is not subject to additional charges when it stops at the busway or enters the buffer zone. Payment system applied is via Cash or use E-ticketing card like Flazz BCA. 
B. Multi-Trip Card Implementation In Jakarta, Indonesia

To implement Multi-Trip in Jakarta, it is required some strategies to implement. By looking at transportation mode's condition in Jakarta that can be integrated, the researcher has some implementation strategies.

a. Transjakarta with Commuter Line (2018)

1) Transjakarta shelters need to be connected to KRL stations, for short distance can use crossing bridge and for a considerable distance can use feeder.

2) Tickets must be integrated by using only one card that can be used for both transportation.

3) Users must tap-in at the departure and tap-out at the destination.

4) PT. Transjakarta and PT. KCJ must develop an appropriate tariff system so that the two sides earn the ideal income according to their respective calculations.

b. Commuter line with Transjakarta and Feeder (2019)

1) Feeder must stand by in Transjakarta bus stop, therefore the user can move faster.

2) Users are no longer need to tap-in the machine to use the feeder.

3) This feeder will be able to deliver the user to the stations, housing, and flats.

c. Transjakarta with Commuter Line and Feeder (2020)

1) Users must purchase a multi trip card that can be used for 3 types of transportation mode that are KRL, Transjakarta, and Feeder.

2) User just tap-in on the entry gate and tap-out on exit gate at the destination and the balance is automatically cut off on the integration tariff.

3) User can enjoy 3 transportation modes directly without additional tariff.

The integrated transportation system above can be described as follows: 


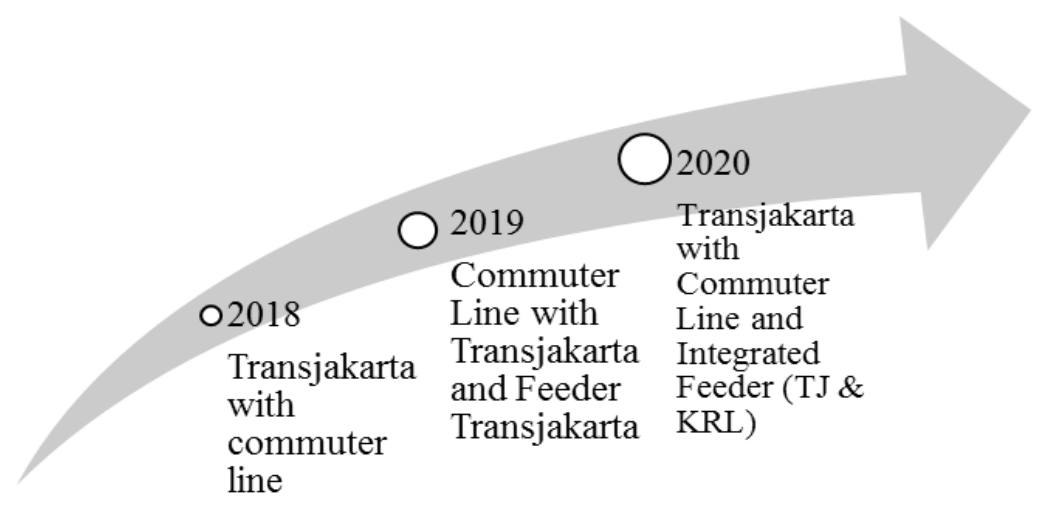

Figure 1. Multi-Trip Strategy Stages

Based on the analysis it can be concluded that multitrip card integration can be done gradually. The first stage integration is between Transjakarta and feeder with commuter line, second between commuter line and Transjakarta and feeder, and third between Transjakarta with commuter line and feeder. In order to make the integration run well, it needs the above phasing process.

3. Implementation of Multi-Trip Ticketing System in Other Country

a. Ticketing System in Germany, Austria and Switzerland

Service enhancement and making an integrated tariff in Hamburg, Wina, and Zurich has improved mass transportation's quality in those cities. This implementation successfully improves public transport user and makes private transport user to switch to use mass transportation. That country has a better transportation system, a varied tariff system, and better service. Related to the varied fees, mass transportation in that country offers monthly ticket and annual ticket at great discount compared to a single travel ticket. In addition to monthly and annually ticket, there are also semester tickets for student, school student, and internship; weekly ticket; a four-day ticket; a three-day ticket; one-day ticket; and strip ticket. Everything is cheaper than a single trip ticket, there are two factors in designing the cost structure.

First is a purchasing system that can use a credit card. Second is a zone tariff structure. 


\section{b. Ticketing System in London, England}

Transportation system in London is already integrated each other, starting from bus, tube (kind of electric train), national rail, tram, and riverboat. Based on the ticket system, the transportation is divided into 9 zones, zone 9 is the outermost zone, the smaller the zone number the closer to the city's center.

The transportation system integration in London makes the ticketing system connected to each other. Using one card, we can enjoy all the transportation there. The transportation's ticket is divided into 2 that is by buying a daily system or known as one-day travel card or by buying Oyster Card which its payment is subscribed.

Oyster card in its payment system is divided into 2 that is with credit system such as one-day travel card or with weekly subscription system, monthly or annually. Using Oyster Card can save travel cost rather than using a one-day travel card.

Table 3. Ticketing system of Public Transportation in different countries

\begin{tabular}{|c|c|c|}
\hline $\begin{array}{c}\text { PUBLIC } \\
\text { TRANSPORTATION }\end{array}$ & ADVANTAGE & DISADVANTAGE \\
\hline $\begin{array}{l}\text { Germany, Austria } \\
\text { And Switzerland }\end{array}$ & 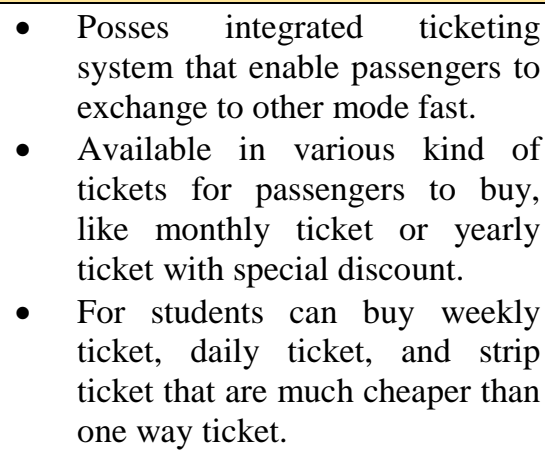 & $\begin{array}{l}\text { - 'Zone fare' system } \\
\text { still applied. }\end{array}$ \\
\hline $\begin{array}{l}\text { London, } \\
\text { Inggris }\end{array}$ & $\begin{array}{l}\text { - Integrated transportation system } \\
\text { for all 'mode' has been running } \\
\text { well that enable passengers to } \\
\text { exchange to other mode easily. } \\
\text { - Passengers can have 'travel card } \\
\text { ticket' for one day (multi-trip) or } \\
\text { 'oyster card ticket' for multi-trip } \\
\text { (monthly subscription). 'Oyster } \\
\text { card ticket' will be cheaper if } \\
\text { you subscribe monthly. }\end{array}$ & $\begin{array}{l}\text { - 'Zone fare' system } \\
\text { still applied. }\end{array}$ \\
\hline
\end{tabular}


Based on the above statement it can be concluded that ticketing system in Germany, Austria, Switzerland and England have many advantages because the ticketing system in those country has been integrated with other transportation mode therefore the passenger become easier and faster in the transportation mode switching. Unfortunately, the ticketing in that country has a weakness, that is using tariff zone system, therefore the use of card is in accordance with each respective zones.

\section{Conclusion}

The results of the study on multi-trip cards in Jakarta by comparing multitrip cards in other countries generate the following conclusion.

1. Ticketing system in Indonesia is already using electronic ticketing therefore the operation is quite good. Ticketing system implementation is already applied by commuter line and Transjakarta unfortunately, it is not integrated yet among the transportation mode. The ticketing system is not integrated yet because the station and shelter bus is not integrated yet and the ticket payment system still uses non-integration card.

2. In the countries like Germany, Austria, Switzerland and England, the implementation of integrated ticketing system is already applied. This implementation successfully improves public transport user and makes private transport's user to switch to use mass transportation. Indonesia needs to implement and replicate an integrated ticketing system that has been enforced in those countries. Viewed from the ticketing system in London, it is very suitable to be applied in Indonesia because it is very easy and cheap so it will be in accordance with people's habit in Indonesia.

3. The multi card trip implementation in Jakarta should be performed gradually. (1) In 2018 Transjakarta will be integrated with commuter line; (2) In 2019 the commuter line with Transjakarta and feeder; (3) In 2020 Transjakarta with commuter line and feeder. 


\section{References}

Ashari, Y. (2016). Analisis Leverage Kenaikan Tarif Progresif dan Jaminan Commuter Line Terhadap Tingkat Okupansi Penumpang ( Studi Kasus Jalur Bogor-Manggarai ), 433-447.

Forum, C. E. (2013). Integrated Ticketing System Of Public Transport In Jakarta Vs Värmland, Sweden, Xxii(January), 1341-1348.

Hadinugrah, D. R., Politik, D., Ilmu, F., \& Politik, I. (2016). Transportasi Di Jabodetabek, (14010113120008).

Halim, J., Case, D. U., Sequence, D., \& Perjalanan, R. (2008). Rencana Perjalanan Untuk Transportasi Umum.

Irpan Tulus, H.S., Sony I., \& Sarinah. (2016). Multimoda Dalam Mewujudkan Visi Logistik Indonesia 2025, 69-84.

Ismiyati, I., Firdaus, M., \& Arubusman, D. A. (2017). Manajemen Pemeliharaan Bus Transjakarta Dalam Mencapai Standar Pelayanan Minimum. Jurnal Manajemen Transportasi Dan Logistik, 3(2), 185. https://doi.org/10.25292/j.mtl.v3i2.92

Kadarisman, M., Gunawan, A., \& Ismiyati, I. (2016). Kebijakan Manajemen Transportasi Darat dan Dampaknya Terhadap Perekonomian Masyarakat di Kota Depok. Jurnal Manajemen Transportasi \& Logistik, 3(1). Retrieved from http://www.ejournal.stmttrisakti.ac.id/index.php/JMTRANSLOG/article/view/72

Karmini dan Siti Fatimah, A. (2015). Kriteria pelayanan sistem tiket terpadu antarmoda angkutan jalan dan pesawat terbang, 65-72.

Kembangarum, Desa. (2006). Efektivitas penggunaan E-Ticketing oleh penumpang Batik Solo Trans , 1-30.

P, D. W. A. (2012). Identifikasi Sistem Pembayaran Transjakarta Menggunakan Smart Card.

Potter, S., \& Skinner, M. J. (2000). On Transport Integration A Contribution To Better Understanding.

Puhe, M., Edelmann, M., \& Reichenbach, M. (2014). Integrated urban eticketing for public transport and touristic sites. https://doi.org/10.2861/49821

Saribanon, E., Sitanggang, R., \& Amrizal. (2016). Kepuasan Pengguna Jasa Transportasi Untuk Meningkatkan Loyalitas the Satisfaction of Transportation'S Customers To Enchance Loyalty. Jurnal Manajemen Transportasi \& Logistik, 3(3), 317-326.

Valarmathi, R., Karthika, G., \& Reader, I. I. I. R. (2014). Smart Ticketing System in Metro Rail, 3(3), 40-43. 